\title{
Water Resources of Lincoln Parish, Louisiana
}

\section{Introduction}

Information concerning the availability, use, and quality of water in Lincoln Parish, Louisiana (fig. 1), is critical for proper water-supply management. The purpose of this fact sheet is to present information that can be used by water managers, parish residents, and others for stewardship of this vital resource. In 2014, about 7.76 million gallons per day $(\mathrm{Mgal} / \mathrm{d})$ of water were withdrawn in Lincoln Parish: $7.69 \mathrm{Mgal} / \mathrm{d}$ from groundwater sources and $0.07 \mathrm{Mgal} / \mathrm{d}$ from surface-water sources ${ }^{1}$ (table 1). Withdrawals for public-supply use accounted for about 89 percent (6.88 Mgal/d) of the total water withdrawn (table 2). Other categories of use included industrial, general irrigation, livestock,

${ }^{1}$ Water-withdrawal data are based on estimated or reported site-specific data and aggregated data, which are distributed to sources. For a full description of water-use estimate methodology, see "Data Collection" in Sargent (2011). Tabulation of numbers in text and tables may result in different totals because of rounding; nonrounded numbers are used for calculation of totals. and rural domestic. Water-use data collected at 5-year intervals from 1960 to 2010 and again in 2014 indicate that water withdrawals peaked in 2000 at $11.01 \mathrm{Mgal} / \mathrm{d}$ (fig. 2).

\section{Groundwater Resources}

The Sparta aquifer is the primary freshwater-bearing aquifer underlying Lincoln Parish (fig. 3). The Cockfield and Cook Mountain aquifers also contain limited amounts of freshwater in some areas of the parish (table 1). The base of fresh groundwater in Lincoln parish (water with a chloride concentration of 250 milligrams per liter [mg/L] or less) is present in the Sparta aquifer at altitudes ranging from less than 300 feet (ft) below the National Geodetic Vertical Datum of 1929 (NGVD 29) in the west-central part of the parish to greater than $600 \mathrm{ft}$ below NGVD 29 in the eastern part (fig. 1; Smoot, 1988).
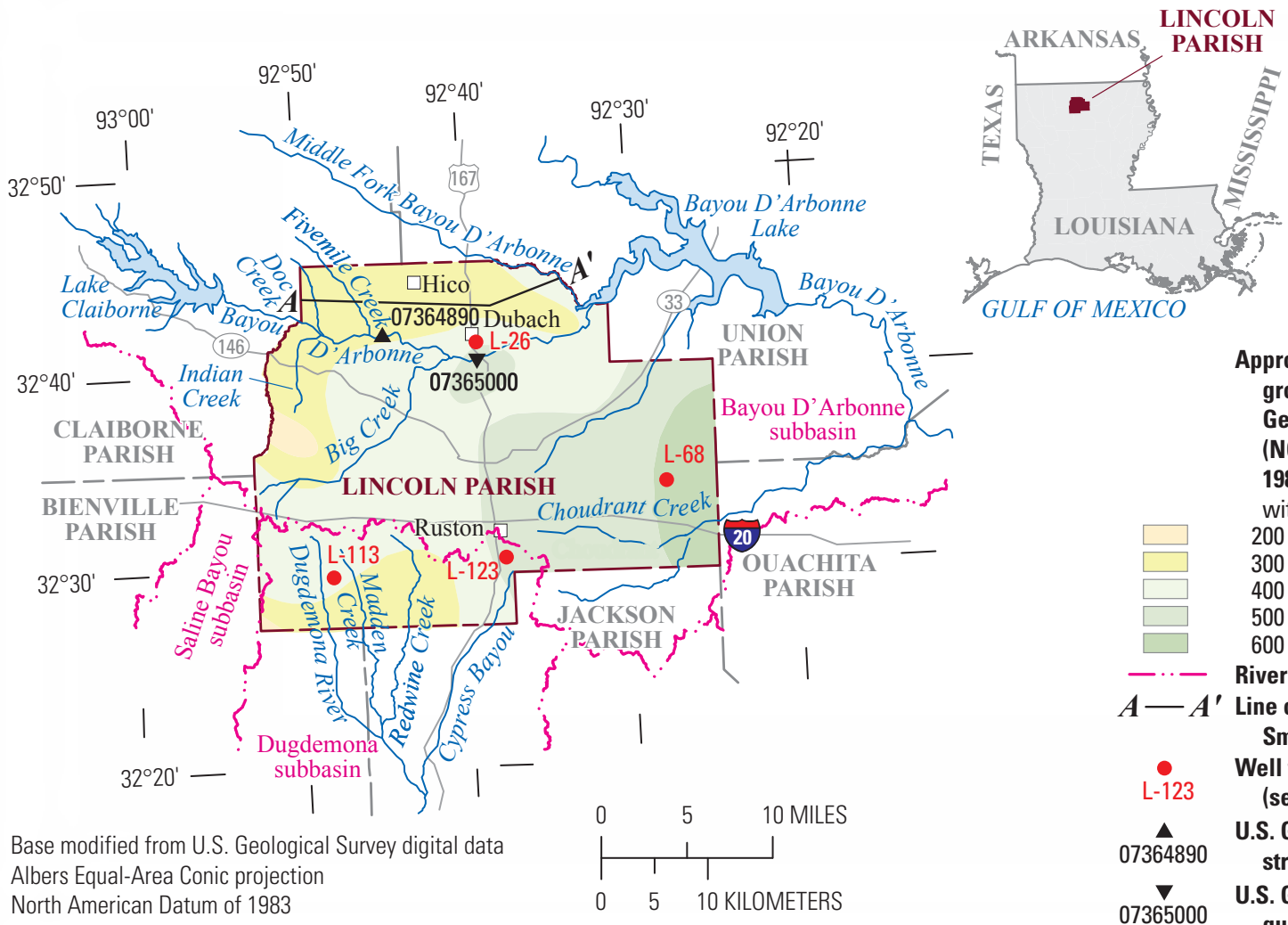

\section{EXPLANATION}

Approximate altitude of base of fresh groundwater, in feet below National Geodetic Vertical Datum of 1929 (NGVD 29) (modified from Smoot, 1988)—Deepest freshwater contained within the Sparta aquifer 200 to 299

300 to 399

400 to 499

500 to 599

600 to 699

- $\cdots-$ River subbasin boundary

$A-A^{\prime}$ Line of section (see fig. 3; modified from Smoot, 1989)

- Well for which hydrograph is shown

L-123 (see fig. 4)

U.S. Geological Survey surface-water 07364890 streamflow site and number

$\underset{07365000}{ }$ U.S. Geological Survey surface-waterquality site and number (see table 4)

Figure 1. Location of study area, Lincoln Parish, Louisiana. 
Table 1. Water withdrawals, in million gallons per day, by source in Lincoln Parish, Louisiana, 2014 (Collier, 2018).

\begin{tabular}{lcc}
\hline \multicolumn{1}{c}{$\begin{array}{c}\text { Aquifer or } \\
\text { surface-water body }\end{array}$} & Groundwater & Surface water \\
\hline Cockfield aquifer & 0.02 & \\
$\begin{array}{l}\text { Sparta aquifer } \\
\text { Miscellaneous surface } \\
\text { waters }\end{array}$ & 7.67 & 0.07 \\
\cline { 2 - 3 } Total & $\mathbf{7 . 6 9}$ & $\mathbf{0 . 0 7}$ \\
\hline
\end{tabular}

Table 2. Water withdrawals, in million gallons per day, by use category in Lincoln Parish, Louisiana, 2014 (Collier, 2018).

$[<$, less than $]$

\begin{tabular}{lccc}
\hline \multicolumn{1}{c}{ Use category } & Groundwater & Surface water & Total \\
\hline Public supply & 6.88 & & 6.88 \\
Rural domestic & 0.19 & & 0.19 \\
Livestock & 0.01 & 0.07 & 0.08 \\
Industrial & 0.62 & & 0.62 \\
General irrigation & & $<0.01$ & $<0.01$ \\
\cline { 2 - 4 } Total & $\mathbf{7 . 6 9}$ & $\mathbf{0 . 0 7}$ & $\mathbf{7 . 7 6}$ \\
\hline
\end{tabular}

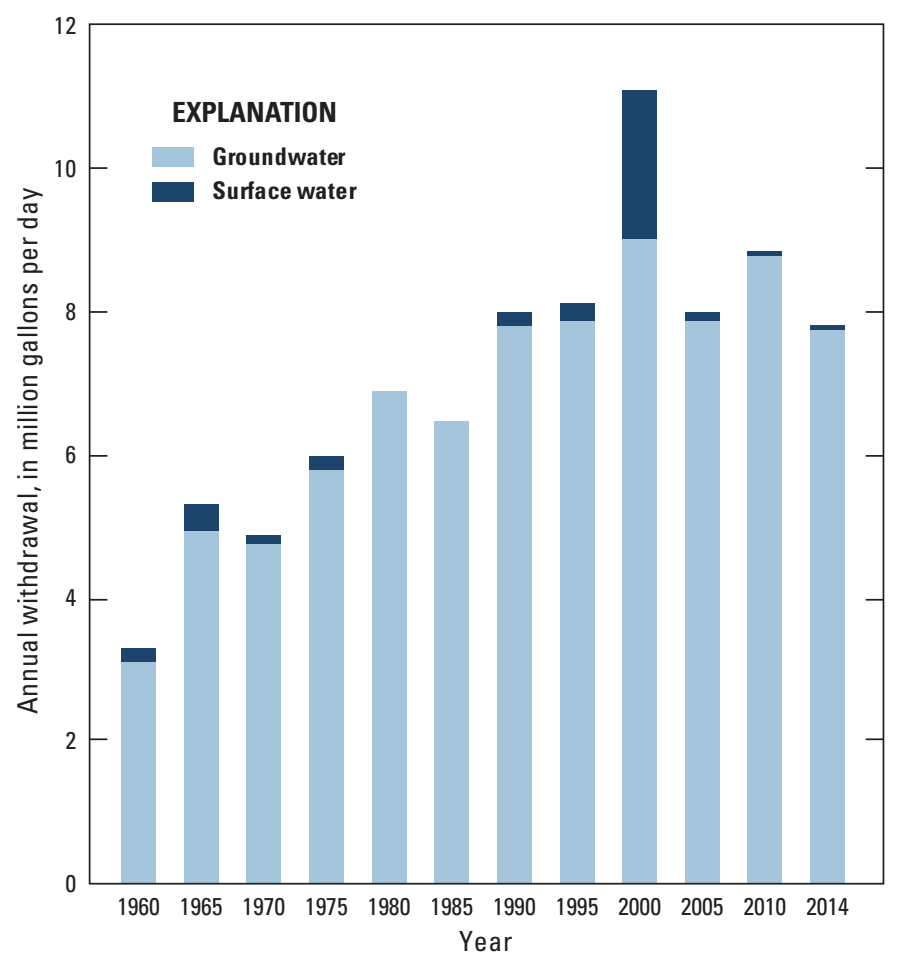

Figure 2. Water withdrawals in Lincoln Parish, Louisiana, 1960-2014 (U.S. Geological Survey, 2017a; Collier, 2018).

\section{Cockfield Aquifer}

The Cockfield aquifer is intermittently present in Lincoln Parish. It is a surficial aquifer in Lincoln Parish and has been removed by erosion in many areas (Sanford, 1973). Where present, the aquifer ranges from 0 to $200 \mathrm{ft}$ thick. The altitude of the base of the aquifer ranges from less than $100 \mathrm{ft}$ above NGVD 29 to greater than $200 \mathrm{ft}$ above NGVD 29 (Ryals, 1984). Sands of the aquifer are generally fine grained but may locally be medium grained and are often interbedded with silt, clay, and lignite (Sanford, 1973; Ryals, 1982). Because of their composition, these sands are not thick enough or spatially extensive enough to supply large quantities of water from wells (Sanford, 1973; Ryals, 1984). The Cook Mountain Formation, which is mostly composed of clay, underlies the Cockfield aquifer and acts as a confining unit, impeding vertical flow between the Cockfield and Sparta aquifers (Sanford, 1973).

State well-registration records listed 16 active water wells screened in the Cockfield aquifer in Lincoln Parish in 2016: 15 domestic wells and 1 irrigation well. Well depths ranged from 27 to $160 \mathrm{ft}$ below land surface with a single reported yield of 5 gallons per minute (gal/min) (Louisiana Department of Natural Resources, 2016). In 2014, less than $0.02 \mathrm{Mgal} / \mathrm{d}$ were withdrawn from the Cockfield aquifer: less than $0.01 \mathrm{Mgal} / \mathrm{d}$ for livestock and about $0.02 \mathrm{Mgal} / \mathrm{d}$ for rural domestic uses (Collier, 2018).

\section{Cook Mountain Aquifer}

The Cook Mountain aquifer is part of the larger Cook Mountain Formation. Although this formation is generally composed of clay and functions as a confining unit between the Sparta aquifer and Cockfield aquifer, localized sand layers within the clay can yield minor supplies of groundwater (Sanford, 1973; Ryals, 1982). The altitude of the base of the formation ranges from below the NGVD 29 in the eastern part of the parish to greater than $100 \mathrm{ft}$ above NGVD 29 in the western part. Formation thickness ranges from less than $150 \mathrm{ft}$ to $250 \mathrm{ft}$, with the formation outcropping or subcropping in much of the parish (Ryals, 1984). Because of the localized nature of the Cook Mountain aquifer, U.S. Geological Survey (USGS) waterlevel data for this aquifer in Lincoln Parish are sparse. However, water levels at well L-123 (USGS site number 323105092374802 ), located south of Ruston and screened in the Cook Mountain aquifer (fig. 1), remained relatively stable with less than $4 \mathrm{ft}$ of total change from 1970 to 1987 (fig. 4).

State well-registration records listed 15 active water wells screened in the Cook Mountain aquifer in Lincoln Parish in 2016: 11 domestic wells, 1 industrial well, and 3 irrigation wells. Well depths ranged from 30 to $188 \mathrm{ft}$ below land surface with reported yields ranging from 4 to $5 \mathrm{gal} / \mathrm{min}$ (Louisiana Department of Natural Resources, 2016).

\section{Sparta Aquifer}

The Sparta aquifer is a regional aquifer underlying much of north-central Louisiana, including all of Lincoln Parish. The altitude of the base of the aquifer ranges from greater than $700 \mathrm{ft}$ below NGVD 29 in the southeastern corner of the parish to less than $400 \mathrm{ft}$ below NGVD 29 in the southwestern corner (Brantly and others, 2002). The altitude of the top of the aquifer ranges from greater than $200 \mathrm{ft}$ above NGVD 29 in the southwestern part of the parish to about $50 \mathrm{ft}$ below NGVD 29 in the northeastern part. In general, the composition of the Sparta aquifer varies by depth and location. The aquifer is composed of sand layers of very fine to medium sand that are interbedded with silt, clay, and lignite. The individual sand layers often do not continue for great distances, but many of these layers are interconnected and form the larger spatially extensive aquifer. The aquifer crops out and is recharged by precipitation in a 


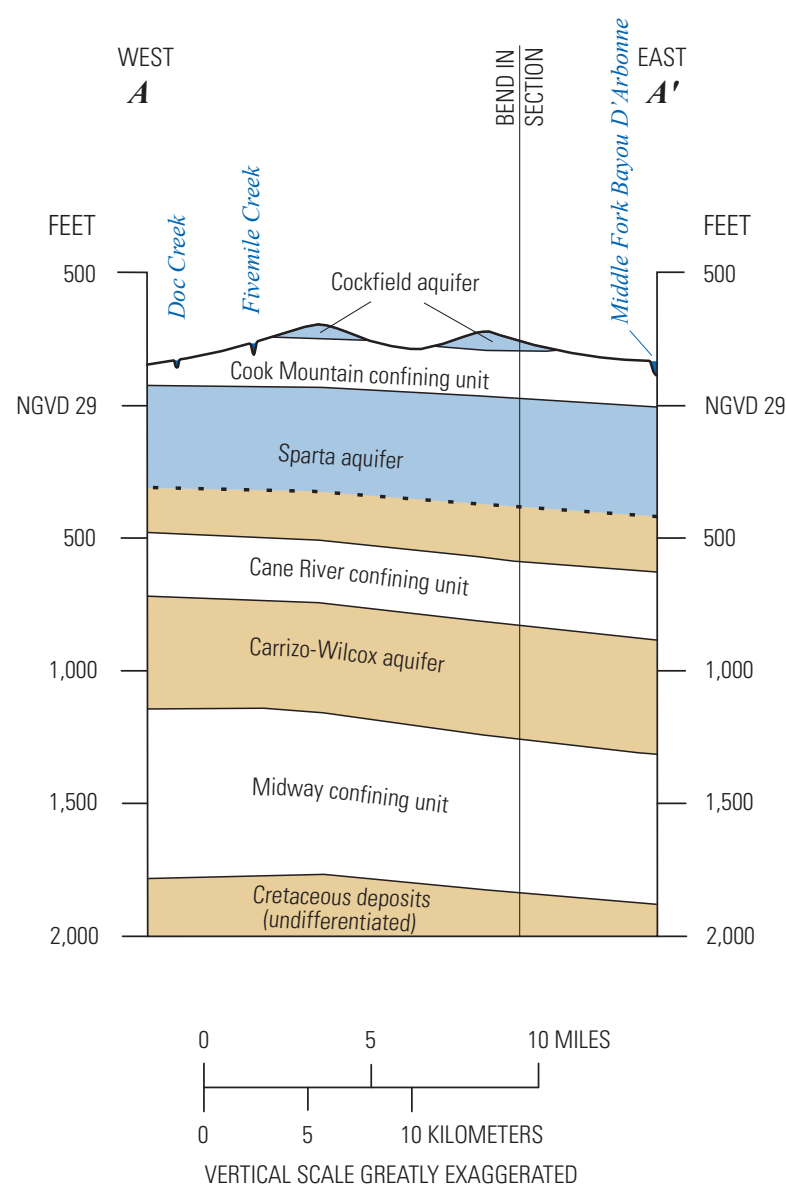

\section{EXPLANATION}

Hydrogeologic unit (modified from Smoot, 1988, 1989)

Aquifer containing freshwater-Freshwater contains a chloride concentration of 250 milligrams per liter or less

Aquifer containing saltwater Confining unit

Hydrogeologic contact (modified from Smoot, 1989) - Separates hydrogeologic units

- - Approximate freshwater/saltwater interface (modified from Smoot, 1988, 1989)

NGVD 29, National Geodetic Vertical Datum of 1929

Figure 3. Idealized west-to-east hydrogeologic section through Lincoln Parish, Louisiana, showing aquifer and confining unit intervals (individual sand and clay layers not shown). (Modified from Smoot, 1988, 1989). Trace of section shown on figure 1.

band extending from the northwest corner of the State to southern Bienville Parish and beyond (Brantly and others, 2002).

A regional survey of the altitude of water levels in wells screened in the Sparta aquifer conducted in 2012 indicated that levels in Lincoln Parish ranged from about $100 \mathrm{ft}$ below NGVD 29 along the eastern border to greater than $60 \mathrm{ft}$ above NGVD 29 in the southwestern corner of the parish. The general groundwater flow direction in the Sparta aquifer in Lincoln Parish is easterly and towards central Ouachita Parish (McGee and Brantly, 2015). Water levels at wells L-26, L-68, and L-113 (USGS site numbers 324141092390501, 323458092275101, and 323013092482001, respectively), located in various parts of the parish and screened in the Sparta aquifer (fig. 1), followed similar patterns of decline during 1970-2016 (fig. 4).

State well-registration records listed 195 active water wells screened in the Sparta aquifer in Lincoln Parish in 2016: 47 domestic wells, 70 public-supply wells, 59 irrigation wells, and 19 industrial wells. Well depths ranged from 270 to $811 \mathrm{ft}$ below land surface with reported yields ranging from 4 to 1,200 gal/min (Louisiana Department of Natural Resources, 2016). In 2014, about $7.67 \mathrm{Mgal} / \mathrm{d}$ were withdrawn from the Sparta aquifer in Lincoln Parish: about $6.88 \mathrm{Mgal} / \mathrm{d}$ for public supply, $0.62 \mathrm{Mgal} / \mathrm{d}$ for industry, $0.17 \mathrm{Mgal} / \mathrm{d}$ for rural domestic use, and less than 0.01 Mgal/d for livestock (Collier, 2018).

\section{Groundwater Quality}

Groundwater samples were collected during 1937-2012 from 94 wells screened in the Sparta aquifer in Lincoln Parish as part of an ongoing program to monitor the State's groundwater resources. These samples had median values for color and $\mathrm{pH}$ and for concentrations of chloride, sulfate, iron, manganese, and dissolved solids that were within the U.S. Environmental Protection Agency's Secondary Maximum Contaminant Levels ${ }^{2}$ (SMCLs) (table 3). The median hardness ${ }^{3}$ value was within the soft range. Localized iron concentrations can greatly exceed the SMCL (300 micrograms per liter). The groundwater quality of the Cockfield and Cook Mountain aquifers underlying Lincoln Parish could not be summarized because of insufficient data.

\footnotetext{
${ }^{2}$ The SMCLs are Federal guidelines regarding cosmetic effects (such as tooth or skin discoloration), aesthetic effects (such as taste, odor, or color), or technical effects (such as damage to water equipment or reduced effectiveness of treatment for other contaminants) of potential constituents of drinking water. SMCLs were established as guidelines by the U.S. Environmental Protection Agency (2016).

${ }^{3}$ Hardness ranges, expressed as milligrams per liter of calcium carbonate, are as follows: 0-60, soft; 61-120, moderately hard; 121-180, hard; greater than 180 , very hard (Hem, 1985).
} 
Table 3. Summary of selected water-quality characteristics for 94 freshwater wells screened in the Sparta aquifer in Lincoln Parish, Louisiana, 1937-2012 (U.S. Geological Survey, 2017b).

[Values are in milligrams per liter, except as noted. ${ }^{\circ} \mathrm{C}$, degrees Celsius; $\mu \mathrm{S} / \mathrm{cm}$, microsiemens per centimeter; $\mathrm{SU}$, standard unit; $\mathrm{CaCO}_{3}$, calcium carbonate; $\mu \mathrm{g} / \mathrm{L}$, micrograms per liter; <, less than; E, estimated; SMCL, Secondary Maximum Contaminant Level established by the U.S. Environmental Protection Agency (2016); NA, not applicable]

\begin{tabular}{|c|c|c|c|c|c|c|c|c|c|c|}
\hline & $\begin{array}{l}\text { Temper- } \\
\text { ature } \\
\left({ }^{\circ} \mathrm{C}\right)\end{array}$ & $\begin{array}{l}\text { Color } \\
\text { (platinum } \\
\text { cobalt } \\
\text { units) }\end{array}$ & $\begin{array}{c}\text { Specific } \\
\text { conduc- } \\
\text { tance, } \\
\text { field } \\
(\mu \mathrm{S} / \mathrm{cm} \\
\text { at } 25^{\circ} \mathrm{C} \text { ) }\end{array}$ & $\begin{array}{l}\text { pH, } \\
\text { field } \\
\text { (SU) }\end{array}$ & $\begin{array}{c}\text { Hard- } \\
\text { ness } \\
\text { (as } \\
\mathrm{CaCO}_{3} \text { ) }\end{array}$ & $\begin{array}{l}\text { Chloride, } \\
\text { filtered } \\
\text { (as CI) }\end{array}$ & $\begin{array}{l}\text { Sulfate, } \\
\text { filtered } \\
\text { (as } \mathrm{SO}_{4} \text { ) }\end{array}$ & $\begin{array}{c}\text { Iron, } \\
\text { filtered, } \\
\text { in } \mu \mathrm{g} / \mathrm{L} \\
\text { (as Fe) }\end{array}$ & $\begin{array}{c}\text { Manga- } \\
\text { nese, } \\
\text { filtered, } \\
\text { in } \mu \mathrm{g} / \mathrm{L} \\
\text { (as Mn) }\end{array}$ & $\begin{array}{l}\text { Dissolved } \\
\text { solids, } \\
\text { filtered }\end{array}$ \\
\hline Median & 24 & 15 & 339 & 7.8 & 4 & 13 & 12 & 190 & $<10$ & 221 \\
\hline 10 th percentile & 23 & 5 & 221 & 7.2 & 1 & 5.1 & 3.4 & 24.5 & $E<1.4$ & 177 \\
\hline 90th percentile & 25.9 & 40 & 498 & 8.6 & 13.7 & 31.6 & 22.4 & 836 & 52 & 289 \\
\hline $\begin{array}{c}\text { Number of } \\
\text { samples }\end{array}$ & 67 & 87 & 91 & 97 & 143 & 143 & 97 & 87 & 59 & 90 \\
\hline $\begin{array}{l}\text { Percentage of } \\
\text { samples that } \\
\text { do not exceed } \\
\text { SMCLs }\end{array}$ & NA & 71 & NA & 88 & NA & 100 & 100 & 63 & 90 & 98 \\
\hline SMCLs & NA & 15 & NA & $6.5-8.5$ & NA & 250 & 250 & 300 & 50 & 500 \\
\hline
\end{tabular}

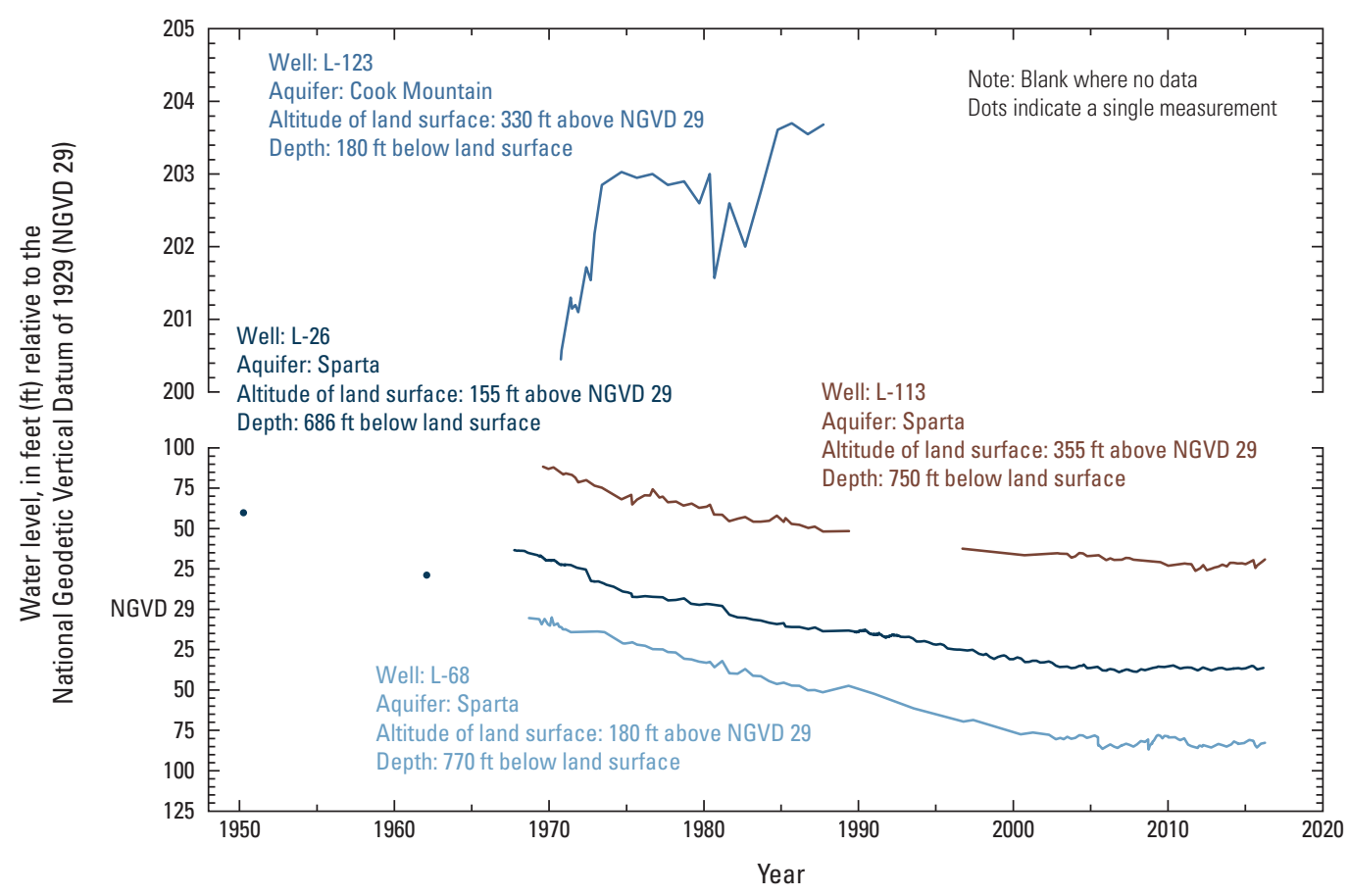

Figure 4. Water levels in wells L-26, L-68, and L-113 screened in the Sparta aquifer and well L-123 screened in the Cook Mountain aquifer in Lincoln Parish, Louisiana (see figure 1 for well locations; U.S. Geological Survey, 2017b). 


\section{Surface-Water Resources}

Surface-water resources in Lincoln Parish are present primarily in two drainage subbasins (fig. 1). The Dugdemona subbasin (Hydrologic Unit Code [HUC] 08040303) drains the south-southwestern part of the parish. The Bayou D'Arbonne subbasin (HUC 08040206) drains the remainder of the parish, except for a small area of the Saline Bayou subbasin (HUC 11140208) along the southwestern parish border (fig. 1). In 2014, about $0.07 \mathrm{Mgal} / \mathrm{d}$ were withdrawn from miscellaneous streams in these subbasins for agricultural purposes, including about $0.07 \mathrm{Mgal} / \mathrm{d}$ for livestock and less than $0.01 \mathrm{Mgal} / \mathrm{d}$ for general irrigation (tables 1-2) (Collier, 2018).

\section{Dugdemona Subbasin}

The Dugdemona subbasin boundary extends from near Ruston west to the border with Bienville Parish. The boundary coincides with a strip of elevated land, and the subbasin occupies the land to the south of that boundary. Some streams in the Dugdemona subbasin in Lincoln Parish include the Dugdemona River, Madden Creek, Redwine Creek, and Cypress Bayou (fig. 1). These streams originate in the elevated land and flow in a general southerly direction in Lincoln Parish. Because these streams originate in the subbasin, their drainage areas and reach lengths are relatively small and little streamflow information is available for this part of the Dugdemona subbasin.

\section{Bayou D'Arbonne Subbasin}

The Bayou D'Arbonne subbasin covers the majority of Lincoln Parish and is primarily drained by Bayou D'Arbonne, which flows generally from west to east in the northern part of the parish. Most of the other, smaller streams in the Bayou D'Arbonne subbasin flow from the north or south into Bayou D'Arbonne, with some streams on the eastern end of the parish flowing in a general easterly direction out of the parish. Flow in Bayou D'Arbonne is regulated by two lakes, Lake Claiborne in Claiborne Parish and
Bayou D'Arbonne Lake in Union Parish, which were completed in the 1960s (Louisiana Department of Wildlife and Fisheries, 2017). The average streamflow at Bayou D'Arbonne near Hico (USGS site number 07364890; fig. 1) was 193 cubic feet per second $\left(\mathrm{ft}^{3} / \mathrm{s}\right)$ during 1980-86 (Carlson and others, 1986). During this period, the maximum streamflow was 11,200 $\mathrm{ft}^{3} / \mathrm{s}$. Tributaries of Bayou D’Arbonne include Big Creek, Indian Creek, Doc Creek, and Fivemile Creek. In the northeastern corner of the parish, Middle Fork Bayou D'Arbonne flows along the border with Union Parish and into Bayou D'Arbonne Lake. East of Ruston, Choudrant Creek flows eastward into Ouachita Parish (fig. 1).

Bayou D'Arbonne Lake borders Lincoln Parish, with most of the lake area in Union Parish. The lake was completed in 1964 through impoundment of Bayou D'Arbonne, Middle Fork Bayou D'Arbonne, and other streams. The lake has a surface area of about 15,000 acres and a watershed of about 1,610 square miles. The lake has an average depth of $8.5 \mathrm{ft}$ with a natural seasonal water fluctuation of 4-6 ft. At capacity, the reservoir has a volume of about 130,000 acre-feet (Shampine, 1971). Some uses of the lake include fishing, skiing, and residential irrigation (Louisiana Department of Wildlife and Fisheries, 2017).

\section{Surface-Water Quality}

USGS surface-water quality data are limited for Lincoln Parish; however, some samples were collected from Bayou D'Arbonne near Dubach (USGS site number 07365000; fig. 1) during 1952-72 (table 4) as part of an ongoing program to monitor the State's surface-water resources. These samples were soft with respect to hardness and median values for $\mathrm{pH}$ and color and concentrations of chloride, sulfate, and dissolved solids were within the SMCLs. The period (1966-68) during which the samples were taken coincides with the impoundment of Bayou D'Arbonne and filling of Lake Claiborne (fig. 1). River impoundment generally would affect water quality; however, in this case, not enough samples were available to make a clear determination.

Water quality in Bayou D'Arbonne Lake varies spatially because of variation in the lake's depth. During warmer months,

Table 4. Summary of selected water-quality characteristics for samples from Bayou D’Arbonne near Dubach, Louisiana, 1952-72 (U.S. Geological Survey, 2017b).

[Values are in milligrams per liter, except as noted. ${ }^{\circ} \mathrm{C}$, degrees Celsius; $\mu \mathrm{S} / \mathrm{cm}$, microsiemens per centimeter; $\mathrm{SU}$, standard unit; $\mathrm{CaCO}_{3}$, calcium carbonate; $\mathrm{SMCL}$, Secondary Maximum Contaminant Level established by the U.S. Environmental Protection Agency (2016); NA, not applicable]

\begin{tabular}{|c|c|c|c|c|c|c|c|c|c|c|c|}
\hline & $\begin{array}{l}\text { Tem- } \\
\text { perature } \\
\left({ }^{\circ} \mathrm{C}\right)\end{array}$ & $\begin{array}{l}\text { Color } \\
\text { (platinum } \\
\text { cobalt } \\
\text { units) }\end{array}$ & $\begin{array}{c}\text { Specific } \\
\text { conduc- } \\
\text { tance, } \\
\text { field } \\
(\mu \mathrm{S} / \mathrm{cm} \text { at } \\
\left.25^{\circ} \mathrm{C}\right)\end{array}$ & $\begin{array}{l}\mathrm{pH}, \\
\text { field } \\
\text { (SU) }\end{array}$ & $\begin{array}{l}\text { Hardness } \\
\text { (as } \mathrm{CaCO}_{3} \text { ) }\end{array}$ & $\begin{array}{l}\text { Calcium, } \\
\text { filtered } \\
\text { (as Ca) }\end{array}$ & $\begin{array}{l}\text { Mag- } \\
\text { nesium, } \\
\text { filtered } \\
\text { (as Mg) }\end{array}$ & $\begin{array}{l}\text { Sodium, } \\
\text { filtered } \\
\text { (as Na) }\end{array}$ & $\begin{array}{l}\text { Chloride, } \\
\text { filtered } \\
\text { (as CI) }\end{array}$ & $\begin{array}{l}\text { Sulfate, } \\
\text { filtered } \\
\text { (as } \mathrm{SO}_{4} \text { ) }\end{array}$ & $\begin{array}{l}\text { Dis- } \\
\text { solved } \\
\text { solids, } \\
\text { filtered }\end{array}$ \\
\hline Median & 16 & 15 & 137 & 6.6 & 25 & 6.5 & 2.1 & 15 & 22.5 & 7.5 & 88 \\
\hline 10th percentile & 8.2 & 10 & 87 & 6.0 & 14 & 4 & 1.0 & 8.1 & 13.5 & 5.6 & 67 \\
\hline 90th percentile & 26 & 38 & 766 & 7.1 & 52 & 16 & 4.2 & 60 & 137 & 15.5 & 187 \\
\hline $\begin{array}{c}\text { Number of } \\
\text { samples }\end{array}$ & 33 & 33 & 36 & 36 & 36 & 36 & 36 & 33 & 36 & 36 & 32 \\
\hline $\begin{array}{l}\text { Percentage of } \\
\text { samples that } \\
\text { do not exceed } \\
\text { SMCLs }\end{array}$ & NA & 61 & NA & 53 & NA & NA & NA & NA & 94 & 100 & 91 \\
\hline SMCLs & NA & 15 & NA & $6.5-8.5$ & NA & NA & NA & NA & 250 & 250 & 500 \\
\hline
\end{tabular}

${ }^{1}$ U.S. Geological Survey site number 07365000. 
the deeper parts of the lake stratify by temperature. Once stratified, the cooler part of the lake's water column will see production of hydrogen sulfide, an increase in color, increases in concentrations of iron and dissolved solids, and decreases in dissolved-oxygen concentrations. A dissolved-oxygen concentration of $5 \mathrm{mg} / \mathrm{L}$ is considered the minimum value for a diverse population of fresh, warmwater biota, including sport fish (Louisiana Department of Environmental Quality, 2008). This stratification does not occur in shallower parts of the lake (Shampine, 1971).

\section{References Cited}

Brantly, J.A., Seanor, R.C., and McCoy, K.L., 2002, Louisiana groundwater map no. 13-Hydrogeology and potentiometric surface of the Sparta aquifer in northern Louisiana, October 1996: U.S. Geological Survey Water-Resources Investigations Report 02-4053, 3 sheets. [Also available at https://la.water.usgs.gov/publications/pdfs/ WRI_02-4053.pdf.]

Carlson, D.D., Dantin, L.J., Garrison, C.R., and Stuart, C.L., 1986, Water resources data, Louisiana, water year 1986: U.S. Geological Survey Water Data Report LA-86-1, 547 p.

Collier, A.L., 2018, Water withdrawals by source and category in Louisiana Parishes, 2014-2015: U.S. Geological Survey data release, https://doi.org/10.5066/F78051VM.

Hem, J.D., 1985, Study and interpretation of the chemical characteristics of natural water ( $3 \mathrm{~d}$ ed.): U.S. Geological Survey Water-Supply Paper 2254, 264 p., accessed February 20, 2013, at http://pubs.er.usgs.gov/ publication/wsp2254.

Louisiana Department of Environmental Quality, 2008, Environmental Regulatory Code, Title 33, Part IX, Subpart 1: Baton Rouge, Louisiana Department of Environmental Quality, accessed June 9, 2009, at http://www.deq.louisiana.gov/portal/tabid/1674/Default.aspx.

Louisiana Department of Natural Resources, 2016, Strategic Online Natural Resources Information System (SONRIS): Louisiana Department of Natural Resources database, accessed August 25, 2016, at http://sonris.com/.

Louisiana Department of Wildlife and Fisheries, 2017, Waterbody Management Plans-Inland: Baton Rouge, Louisiana Department of Wildlife and Fisheries, accessed March 6, 2017, at http://www.wlf. louisiana.gov/fishing/waterbody-management-plans-inland.

McGee, B.D., and Brantly, J.A., 2015, Potentiometric surface, 2012, and water-level differences, 2005-12, of the Sparta aquifer in northcentral Louisiana: U.S. Geological Survey Scientific Investigations Map 3313, accessed January 18, 2017, at https://pubs.er.usgs.gov/ publication/sim3313.

Ryals, G.N., 1982, Regional geohydrology of the northern Louisiana salt-dome basin, Part I, conceptual model and data needs: U.S. Geological Survey Open-File Report 82-343, 27 p., 2 pls. [Also available at https://pubs.er.usgs.gov/publication/ofr82343.]

Ryals, G.N., 1984, Regional geohydrology of the northern Louisiana salt-dome basin, Part II, geohydrologic maps of the tertiary aquifers and related confining layers: U.S. Geological Survey Water-Resources Investigations Report 83-4135, 6 p., 7 pls. [Also available at https:// pubs.er.usgs.gov/publication/wri834135.]

Sanford, T.H., Jr., 1973, Water resources of the Ruston area, Louisiana: Louisiana Department of Public Works Water Resources Technical Report no. 8, 32 p. [Also available at https://la.water.usgs.gov/ publications/pdfs/TR8.pdf.]
Sargent, B.P., 2011, Water use in Louisiana, 2010: Louisiana Department of Transportation and Development Water Resources Special Report no. 17, 135 p. [Also available at https://la.water.usgs. gov/publications/pdfs/WaterUse2010.pdf.]

Shampine, W.J., 1971, Chemical, biological, and physical data for the major lakes and reservoirs in Louisiana: Louisiana Department of Public Works Basic Records Report no. 5, 98 p.

Smoot, C.W., 1988, Louisiana hydrologic atlas map no. 3-Altitude of the base of freshwater in Louisiana: U.S. Geological Survey Water-Resources Investigations Report 86-4314, 1 sheet, accessed November 2, 2011, at https://pubs.er.usgs.gov/publication/ wri864314.

Smoot, C.W., 1989, Louisiana hydrologic atlas map no. 4Geohydrologic sections of Louisiana: U.S. Geological Survey Water-Resources Investigations Report 87-4288, 1 sheet. [Also available at https://pubs.usgs.gov/wri/1987/4288/plate-1.pdf.]

U.S. Environmental Protection Agency, 2016, Secondary Drinking Water Standards - Guidance for nuisance chemicals, accessed April 13, 2016, at https://www.epa.gov/dwstandardsregulations/ secondary-drinking-water-standards-guidance-nuisance-chemicals.

U.S. Geological Survey [USGS], 2017a, U.S. Geological Survey Water Resources Cooperative Program-Louisiana Water Use Program, accessed February 16, 2017, at https://la.water.usgs.gov/WaterUse/ default.asp.

U.S. Geological Survey [USGS], 2017b, USGS water data for the Nation: U.S. Geological Survey National Water Information System database, accessed February 2, 2017, at https://doi.org/10.5066/ F7P55KJN.

This fact sheet has been prepared by the U.S. Geological Survey (USGS), in cooperation with the Louisiana Department of Transportation and Development (DOTD), as part of a program to document water use, availability, and quality in the parishes of Louisiana. Information on the availability, past and current water use, use trends, and water quality from groundwater and surface-water sources in the parish is presented here. Previously published reports (see References Cited section) and data stored in the USGS National Water Information System (USGS, 2017b) are the primary sources of the information presented here. Special thanks are given to Doug Taylor, Director, and Zahir "Bo" Bolourchi (retired), DOTD Cooperative Program with the USGS.

\section{By Vincent E. White}

\section{For additional information, contact:}

Director, USGS Lower Mississippi-Gulf Water Science Center 3535 S. Sherwood Forest Blvd., Suite 120

Baton Rouge, LA 70816

E-mail: gs-w-lmg_center_director@usgs.gov

Fax: (225) 298-5490

Telephone: (225) 298-5481

Home Page: http://la.water.usgs.gov 